\title{
Taxonomic Status of Micrococcus agilis Ali-Cohen 1889
}

\author{
M. KOCUR AND K. H. SCHLEIFER \\ Czechoslovak Collection of Microorganisms, J. E. Purkynè University, Brno, CSSR, and Lehrstuhl für \\ Mikrobiologie, Universität München, 8 München 19, Germany
}

An amended description of Micrococcus agilis Ali-Cohen 1889 is proposed on the basis of a taxonomic study of five strains. Strain ATCC 966 (= CCM $2390=$ NCTC 7509) is designated as the neotype strain of M. agilis Ali-Cohen 1889.

Micrococcus agilis Ali-Cohen 1889 is undoubtedly among the first described flagellated micrococci. However, no type culture of $M$. agilis seems to exist in any strain collection. The strains labeled as $M$. agilis (ATCC 988 and 9814) maintained in the American Type Culture Collection were found to be nonmotile (13).

We received several strains of flagellated micrococci that resemble $M$. agilis in their characteristics. The aim of the present paper is to give a revised description of $M$. agilis AliCohen 1889 and to designate the neotype strain.

\section{MATERIALS AND METHODS}

Organisms. Five strains of aerobic, dark rose-redpigmented micrococci were investigated (Table 1). The strains were maintained on nutrient agar at $4 \mathrm{C}$. All morphological, nutritional, and biochemical studies were made on cultures grown at $25 \mathrm{C}$.

Methods. Morphological properties, Gram staining, starch hydrolysis, and nitrate reduction were determined according to methods described in the Manual of Microbiological Methods (4). Most of the cultural and biochemical methods were those described by Mortensen and Kocur (15). For glucose utilization, the medium recommended by the ICSB Subcommittee on Taxonomy of Staphylococci and Micrococci was used (19). Gelatin hydrolysis was determined by the method of Clarke (3). Production of indole, hydrogen sulfide, acetoin, phenylalanine deaminase, and arginine dihydrolase, the methyl red test, and growth on Simmons' citrate agar were studied by methods recommended by Ewing (6). Oxidase was detected by the method of Gaby and Hadley (7). Salt tolerance was observed on nutrient agar with $5,7.5,10$, or $15 \% \mathrm{NaCl}$. Sensitivity to antibiotics was determined by the use of Oxoid multodisks.

The peptidoglycan type of the cell wall was determined by the method of Schleifer and Kandler (17).

\section{RESULTS AND DISCUSSION}

Morphology. All five strains examined were gram-positive cocci, 0.8 to $1.2 \mu \mathrm{m}$ in diameter, arranged in pairs and in tetrads. Each cell was motile, with one to three flagella (Fig. 1). The only exception was strain CCM 2131, which was not flagellated.
TABLE 1. List of strains used ${ }^{a}$

\begin{tabular}{|c|c|}
\hline $\begin{array}{c}\text { Micrococcus } \\
\text { agilis } \\
\text { CCM no. }\end{array}$ & Other name or no. \\
\hline 2131 & $\begin{array}{l}\text { M. agilis ATCC } 998=\text { NCTC } 2676 \\
\text { (Boháček et al. 1969; Kocur and } \\
\text { Páčová 1970). }\end{array}$ \\
\hline 2390 & $\begin{array}{l}\text { M. roseus ATCC } 966=\text { NCTC } 7509= \\
\text { NCDO } 983=\text { W.O.219 (Boháček et } \\
\text { al. 1969; Kocur and Páčová 1970). }\end{array}$ \\
\hline 2539 & $M$. roseus strain R-27 (Ghuysen 1968). \\
\hline 2687 & $\begin{array}{l}\text { W. E. Kloos strain KE11 (Kloos et al. } \\
\text { 1974). }\end{array}$ \\
\hline 2688 & W. O. Back strain D5. \\
\hline
\end{tabular}

${ }^{a}$ Abbreviations: ATCC, American Type Culture Collection, Rockville, Md.; CCM, Czechoslovak Collection of Microorganisms, Brno; NCDO, National Collection of Dairy Organisms, Reading, England; NCTC, National Collection of Type Cultures, London, England; W.O., Vitamin Research Station, Walton Oaks, Tadworth, Surrey, England.

Cultural characteristics. Colonies of all strains were circular, entire, slightly convex, smooth, and matted. All produced a dark rose-red, water-insoluble pigment on most solid media tested. In nutrient broth all of the strains formed sediment but no turbidity.

Biochemical characteristics. Results of the biochemical tests are given in Table 2. The mol\% values of the guanine plus cytosine $(\mathrm{G}+\mathrm{C})$ content in the deoxyribonucleic acid (DNA) of three strains ranged from 67 to $69 \%$.

Cell wall peptidoglycan type. The peptidoglycan of the cell wall of all strains studied was of the L-Lys-L-Thr-L-Ala ${ }_{3}$ type. A fragment of the primary structure of the peptidoglycan is depicted in Fig. 2.

Susceptibility to antibiotics. All of the strains were susceptible to penicillin, streptomycin, chloramphenicol, tetracycline, erythromycin, novobiocin, ampicillin, carbenicillin, lincomycin, gentamycin, and lysozyme.

Our results agree, with minor exceptions, with the original description of $M$. agilis AliCohen 1889. The differences were found in 
gelatin hydrolysis, nitrate reduction, and production of acid from glucose. These discrepancies may be attributed to different techniques for the detection of the above test used by Ali-Cohen and us. In spite of these differences, we suggest that the five strains studied belong to $M$. agilis. An amended description of this species is given below.

Micrococcus agilis Ali-Cohen 1889.

Obj.syn.: Planosarcina agilis (Ali-Cohen) Migula 1894. á. gi. lis. L.adj. agilis = agile.

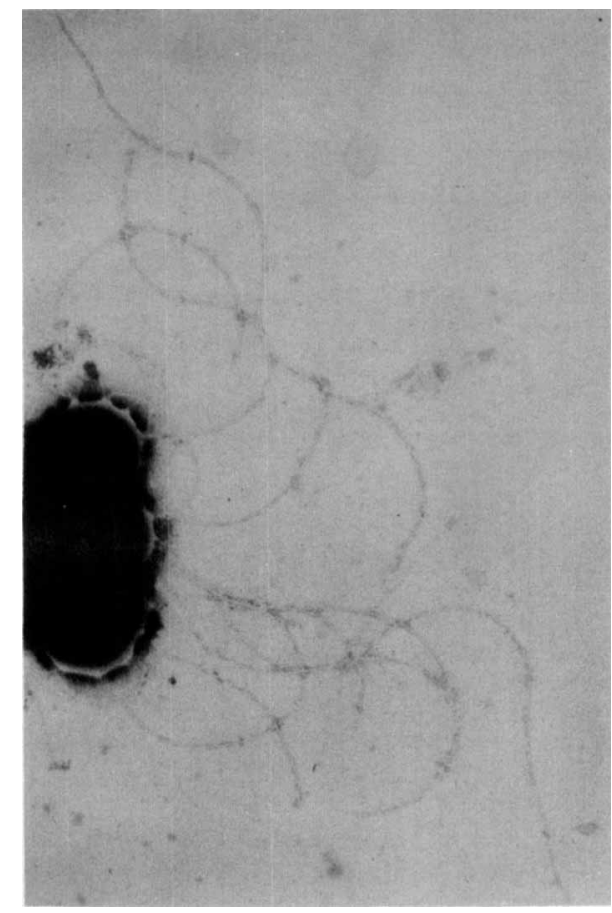

Fig. 1. Flagella of Micrococcus agilis. Negatively stained preparation. $\times 11,500$.
(Figures in parenthesis are percentages of strains positive).

Spheres 0.8 to $1.2 \mu \mathrm{m}$ in diameter, occurring in pairs and tetrads. Motile by means of one or three flagella. Nonmotile strains may occur. Nonsporeforming. Gram positive.

The cell wall peptidoglycan is of the L-Lys-LThr-L-Ala ${ }_{3}$ type.

Agar colonies: Circular, entire, slightly convex, smooth, matted. Produce dark rose-red, water-insoluble pigment.

Agar slant: Good growth with dark rose-red pigment.

Nutrient broth: Clear; sediment is formed.

Chemo-organotrophic: Metabolism is respiratory.

Acid and gas are not produced from glucose or other carbohydrates in standard medium (method of Subcommittee [19]).

Catalase is produced $(100 \%)$.

Porphyrin respiratory enzymes are produced (100\%) (method of Deibel and Evans [5]).

Acetylmethylcarbinol is not produced.

$\beta$-Galactosidase ( 0 -nitrophenyl- $\beta$-D-galactopyranoside test) is positive.

Methyl red is negative.

Indole and hydrogen sulfide are not produced.

Nitrate is not reduced.

Gelatin is hydrolyzed $(100 \%)$ (method of Clarke [3]).

Starch is hydrolyzed $(90 \%)$.

Esculin may be hydrolyzed $(100 \%)$.

Oxidase is produced $(100 \%)$ (method of Gaby and Hadley [7]).

Simmons' citrate: No growth.

Arginine dihydrolase, ornithine, and lysine decarboxylase and phenylalanine deaminase are not produced.

Tween 80 may be split $(50 \%)$.

Deoxyribonuclease may be produced.

TABLE 2. Biochemical characteristics of strains of Micrococcus agilis ${ }^{a}$

\begin{tabular}{c|c|c|c|c|c}
\hline $\begin{array}{c}\text { Strain } \\
\text { CCM no. }\end{array}$ & mol\% G+C & $\begin{array}{c}\text { Starch } \\
\text { hydrolysis }\end{array}$ & $\begin{array}{c}\text { Deoxyribo- } \\
\text { nuclease }\end{array}$ & $\begin{array}{c}\text { Esculin } \\
\text { hydrolysis }\end{array}$ & Tween 80 \\
\hline 2539 & 67.0 & $+^{c}$ & + & + & - \\
2131 & 68.4 & + & + & + & + \\
2390 & 69.0 & + & + & + & + \\
2687 & NT & - & + & + & - \\
2688 & NT & + & + & + \\
\hline
\end{tabular}

${ }^{a}$ All strains tested positive to catalase, benzidine, oxidase and $\beta$-galactosidase ( $O$-nitrophenyl- $\beta$-D-galactopyranoside) and hydrolyzed gelatin. None of the strains produced acid from glucose, lactose, or mannitol, produced acetoin, reduced nitrate, produced phosphatase, urease, tyrosinase, indole, hydrogen sulfide, arginine dihydrolase, ornithine, and lysine decarboxylase, phenylalanine deaminase, or hemolysis, or grew on Simmons' citrate agar or on nutrient agar with $5 \% \mathrm{NaCl}$.

${ }^{b}$ Data from Boháček et al. (2) and Kocur and Boháček (unpublished data).

${ }^{c}$ Reaction: +, Positive; - , negative; ', weak; NT, not tested. 
Urease, tyrosinase, and phosphatase are not produced.

$\beta$-Hemolysis is not produced.

Aerobic.

Good growth between 20 to $30 \mathrm{C}$. No growth at $37 \mathrm{C}$.

No growth on medium with $5 \% \mathrm{NaCl}$.

Susceptibility to antibiotics: Susceptible to penicillin, streptomycin, chloramphenicol, tetracycline, erythromycin, novobiocin, ampicillin, carbenicillin, gentamycin, and lysozyme.

Saprophytic.

Habitat: Water, soil, human skin.

$\mathrm{G}+\mathrm{C}$ content of the DNA is 67.0 to $69.0 \mathrm{~mol} \%$ (2).

Strain ATCC 966 ( = NCTC $7509=$ NCDO 983 = CCM 2390) is designated here is the neotype strain of $M$. agilis. A description of this strain follows.

Spheres 0.9 to $1.1 \mu \mathrm{m}$ in diameter, occurring in pairs and tetrads. Motile by means of one or two flagella. Nonsporeforming. Gram positive.

The cell wall contains peptidoglycan of the L-Lys-L-Thr-L-Ala type. $^{2}$

Agar colonies: Circular, entire, 2 to $3 \mathrm{~mm}$ in diameter, slightly convex, smooth, matted, dark rose-red pigmented.

Agar slant: Good growth with dark rose-red, water-insoluble pigment.

Nutrient broth: No turbidity, only sediment is formed.

Chemo-organotrophic: Metabolism is respiratory.

Strictly aerobic.

$\mathrm{G}+\mathrm{C}$ content of the DNA $(69.0 \mathrm{~mol} \%)$ and biochemical characteristics of the strain are given in Table 2.

Susceptibility to antibiotics: Susceptible to penicillin, streptomycin, chloramphenicol, tetracycline, erythromycin, ampicillin, carbenicillin, gentamycn, novobiocin, and lysozyme.

$M$. agilis can be distinguished from the other

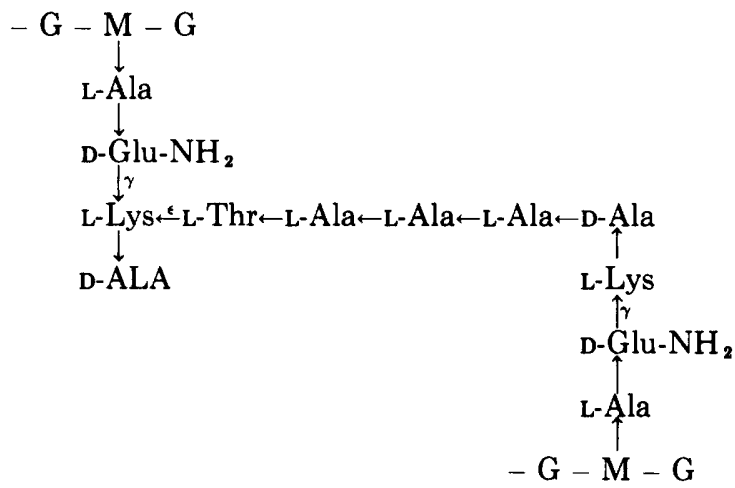

Fig. 2. Fragment of the primary structure of the peptidoglycan types of M. agilis. Abbreviations: $M$, $N$-acetylmuramic acid; $G, N$-acetylglucosamine.

TABLE 3. Differentiation of species of the genus Micrococcus

\begin{tabular}{|c|c|c|c|c|c|c|c|c|c|c|c|c|}
\hline Species $^{a}$ & Pigment & 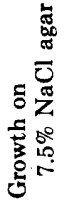 & $\begin{array}{c}0 \\
5 \\
0 \\
+5 \\
5 \\
5 \\
0 \\
0 \\
5\end{array}$ & 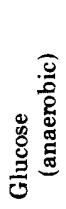 & 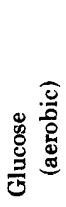 & 吾竞 & 总 & 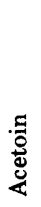 & 旁 & 至 & 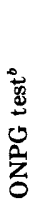 & 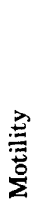 \\
\hline Micrococcus luteus & Yellow & $t^{c}$ & + & - & - & + & - & - & - & - & - & - \\
\hline M. lylae & None & + & + & - & - & + & - & - & - & - & - & - \\
\hline M. varians & Yellow & + & + & - & + & d & + & & - & - & - & - \\
\hline$M$. roseus & Pink & + & + & - & + & - & + & d & - & - & - & - \\
\hline M. agilis & Red & - & - & - & - & + & - & - & - & + & + & + \\
\hline M. kristinae & Pale orange & + & + & + & + & - & - & + & - & + & - & - \\
\hline M. nishinomiyaensis & Orange & - & + & - & $\mathrm{d}$ & + & + & - & - & - & - & - \\
\hline M. sedentarius & Cream white & + & + & - & - & + & - & - & + & - & - & - \\
\hline M. halobius ${ }^{d}$ & None & + & + & - & + & - & - & - & - & - & - & - \\
\hline
\end{tabular}

a For further details, see references 9 and 10

${ }^{b} \mathrm{ONPG}, o-\mathrm{Nitrophenyl- \beta}-\mathrm{D}$-galactopyranoside.

${ }^{c}$ Reaction: +, Positive; -, negative; $d$, different.

${ }^{d}$ Requires at least $5 \% \mathrm{NaCl}$ in the medium. Its description is based on characteristics of single strain only (16). 
species of the genus Micrococcus by means of characteristics mentioned in Table 3 . It is apparent that $M$. agilis differs from $M$. roseus in eight characters, which supports its recognition as a separate species.

\section{ACKNOWLEDGMENT}

We are grateful to D. Sišáková for the negatively stained preparation of the cells of Micrococcus agilis.

\section{REPRINT REQUESTS}

Address reprint requests: Dr. M. Kocur, Czechoslovak Collection of Microorganisms, $66243 \mathrm{Bmo}$, CSSR.

\section{LITERATURE CITED}

1. Ali-Cohen, C. H. 1889. Eigenbewegung bei Mikrokokken. Zentrabl. Bakteriol. Parasitenkd. Infektionskr. Hyg. I Abt. Orig. 6:33-36.

2. Boháček, J., M. Kocur, and T. Martinec. 1969. Deoxyribonucleic acid base composition of Micrococcus roseus. Antonie van Leeuwenhoek J. Microbiol. Serol. 35:185-188.

3. Clarke, S. 1953. A simplified plate method for detecting gelatine liquefying bacteria. J. Clin. Pathol. 6:246-248.

4. Conn, H. J., and M. W. Jennison (ed.). 1957. Manual of microbiological methods. McGraw-Hill, New York.

5. Deibel, R. H., and J. B. Evans. 1960. Modified benzidine test for the detection of cytochrome-containing respiratory systems in microorganisms. J. Bacteriol. 79:356-360.

6. Ewing, W. H. 1960. Enterobacteriaceae. Biochemical methods for group differentiation. Health Service Publ. 734:1-30.

7. Gaby, W. L., and C. Hadley. 1957. Practical laboratory test for the identification of Pseudomonas aeruginosa.
J. Bacteriol. 74:356-358.

8. Ghuysen, J. M. 1968. Use of bacteriolytic enzymes in determination of wall structure and their role in cell metabolism. Bacteriol. Rev. 32:425-464.

9. Hucker, G. J., and R. S. Breed. 1957. Genus Micrococcus, p. 462 . In R. S. Breed, E. G. D. Murray, and N. R. Smith (ed.), Bergey's manual of determinative bacteriology, 7th ed. Tindall and Cox, London.

10. Kloos, W. E., T. G. Tornabene, and K. H. Schleifer. 1974. Isolation and characterization of micrococci from human skin, including two new species: Micrococcus lylae and Micrococcus kristinae. Int. J. Syst. Bacteriol. 24:79-101.

11. Kocur, M., and Z. Páčová. 1970. The taxonomic status of Micrococcus roseus Flügge, 1886. Int. J. Syst. Bacteriol. 20:233-240.

12. Kocur, M., Z. Páčová, W. Hodgkiss, and T. Martinec. 1970. The taxonomic status of the genus Planococcus Migula 1894. Int. J. Syst. Bacteriol. 20:241-248.

13. Leifson, E. 1964. Micrococcus eucinetus n. sp. Int. Bull. Bacteriol. Nomencl. Taxon. 14:41-44.

14. Migula, W. 1894. Über ein neues System der Bakterien. Arb. Bakteriol. Inst. Karlsruhe 1:235-238.

15. Mortensen, N., and M. Kocur. 1967. Correlation of DNA base composition and acid formation from glucose of staphylococci and micrococci. Acta Pathol. Microbiol. Scand. 69:445-457.

16. Onishi, H., and M. Kamekura. 1972. Micrococcus halobius sp. n. Int. J. Syst. Bacteriol. 22:233-236.

17. Schleifer, K. H., and O. Kandler. 1970. Amino acid sequence of the murein of Planococcus and other Micrococcaceae. J. Bacteriol. 103:387-392.

18. Schleifer, K. H., and M. Kocur. 1973. Classification of staphylococci based on the chemical composition of the cell wall. Arch. Mikrobiol. 93:65-85.

19. Subcommittee on Taxonomy of Staphylococci and Micrococci. 1965. Recommendation. Int. Bull. Bacteriol. Nomencl. Taxon. 15:109-111. 